\title{
Influence of sodium silicate modulus on iron ore flotation with sodium oleate
}

\author{
R.S. Arantes, R.M.F. Lima* \\ Department of Mining Engineering, Federal University of Ouro Preto, Campus Morro do Cruzeiro, CEP.: 35.400-000 Ouro Preto, Minas Gerais, Brazil
}

\section{A R T I C L E I N F O}

\section{Article history:}

Received 7 December 2012

Received in revised form 3 September 2013

Accepted 8 September 2013

Available online 14 September 2013

\section{Keywords:}

Iron ore

Sodium silicate modulus

Sodium oleate

flotation

\begin{abstract}
A B S T R A C T
This paper presents the influence of sodium silicate modulus on iron ore flotation with sodium oleate collector. Bench flotation tests were performed at $\mathrm{pH} 7$ with actual iron ore from Quadrilátero Ferrífero, Brazil, with $42.8 \% \mathrm{Fe}$ and $37.2 \% \mathrm{SiO}_{2}$. Iron recovery averaged above $90 \%$ and the Fe contents in the concentrate were above $55 \%$. The highest values of $\mathrm{Fe}$ grade and lowest of $\mathrm{SiO}_{2}$ were obtained with low levels of pulp density and sodium silicate dosage and with high level of sodium oleate. Increase of sodium silicate modulus had a small influence on response variables.
\end{abstract}

(c) 2013 Elsevier B.V. All rights reserved.

\section{Introduction}

Factors such as mineralogy, $\mathrm{Fe}$ and $\mathrm{SiO}_{2}$ grades, and particle size distribution are important for choosing the most suitable concentration method (gravity separation, magnetic separation, and flotation) to be used in low grade iron ore beneficiation (Araújo et al., 2003). There are two possible flotation routes to concentrate low grade iron ore: direct flotation of iron oxides with anionic collectors (fatty acid, hydroxamate, and sulphonate) and inverse flotation of siliceous gangue with both cationic (amine) and anionic collectors with previous siliceous gangue activation by a polyvalent metal such as $\mathrm{Ca}^{2+}$ (Houot, 1983; Uwadiale, 1992).

In iron oxide (hematite, magnetite, and goethite) flotation, its maximum recovery with the collector sodium oleate is achieved at the neutral pH value (Kulkarni and Somasundaran, 1975; Luz, 1996; Lopes and Lima, 2009). But, with higher collector dosages, high hematite recoveries are possible at both acid and alkaline pH values (Gutierréz and Iskra, 1977; Jung et al., 1987; Shibata and Fuerstenau, 2003; Lopes and Lima, 2009).

Soluble sodium silicate or water glass is the most widely used dispersant of slime in wet mineral processing. It is also very frequently used as depressant in nonmetallic flotation such as phosphate flotation in order to depress siliceous gangue and carbonates (Zhang et al., 2007). In iron ore wet processing, especially in flotation, sodium silicate is widely used to disperse the kaolinite over a wide range of $\mathrm{pH}$ values

\footnotetext{
* Corresponding author. Tel.: + 55313559 1590; fax: + 553135591593 E-mail address: rosa@demin.ufop.br (R.M.F. Lima).
}

(Al-Wakeel and El-Rahman, 2006; $\mathrm{Ma}, 2011$ ). The $\mathrm{SiO}_{2}$ to $\mathrm{Na}_{2} \mathrm{O}$ ratio (modulus) of sodium silicate varies from 1 to 3.75 (Sollenberger and Greenwalt, 1958; Leja, 1982). The products of sodium silicate hydrolysis are monomeric, polymeric, and colloidal species, depending on the $\mathrm{pH}$ value, concentration, and ratio of $\mathrm{SiO}_{2}$ to $\mathrm{Na}_{2} \mathrm{O}$ (sodium silicate modulus) (Lagerström, 1959; Ingri, 1959; Sjöberg et al., 1985; Svensson at al., 1986; Bass and Turner, 1997).

This paper presents the influence of sodium silicate modulus on iron ore flotation with sodium oleate collector. Bench flotation tests were performed at pH 7 with actual iron ore from Quadrilátero Ferrífero, Brazil.

\section{Materials and methods}

\subsection{Ore sample}

The iron ore received in laboratory $(200.7 \mathrm{~kg}$ ) was previously wet ground in ball mill (pulp of 70 wt.\%) and classified in pilot plant of Vale Company inside the fraction size normally used in iron ore flotation $(90 \%-147 \mu \mathrm{m})$ and before the bench flotation tests, it was filtrated, dried at $100{ }^{\circ} \mathrm{C}$, homogenised and quartered to obtain subsamples, which were previously deslimed before the bench flotation tests.

The desliming process consisted of the following steps. First, the iron ore pulp density of $15 \mathrm{wt} . \%$ at natural $\mathrm{pH}(\sim 7)$ was prepared and stirred in flotation cell (Cimaq) at 1400 RPM speed. After 3 min, the flotation cell was turned off, and after $1 \mathrm{~min}$, the mud was removed. This operation was performed three times. Finally, the deslimed iron ore was dried at $100{ }^{\circ} \mathrm{C}$. 
Table 1

Chemical composition and loss on ignition (LOI) of iron ore from Quadrilátero Ferrífero, Brazil, after desliming operation.

\begin{tabular}{llllllll}
\hline \multicolumn{2}{l}{ Content (\%) } \\
\hline $\mathrm{Fe}_{\text {Total }}$ & $\mathrm{SiO}_{2}$ & $\mathrm{Al}_{2} \mathrm{O}_{3}$ & $\mathrm{P}$ & $\mathrm{Mn}$ & $\mathrm{CaO}$ & $\mathrm{TiO}_{2}$ & LOI \\
\hline 42.8 & 37.2 & 0.26 & 0.073 & 0.043 & 0.011 & 0.009 & 0.94 \\
\hline
\end{tabular}

The chemical compositions and loss on ignition (LOI) of iron ore from Quadrilátero Ferrífero, Brazil, used in bench flotation tests are presented in Table 1.

The minerals identified in the iron ore sample studied were hematite (He), goethite (Go), and quartz (Qz), which is in accordance with the chemical composition presented in Table 1 . Probably in this sample there are traces of kaolinite $\left(\mathrm{Al}_{2} \mathrm{O}_{3}, 0.26 \%\right)$, which was not identified in the X-ray diffractogram due to its small proportion in the sample.

The $\mathrm{P}_{80}$ of iron ore after desliming operation is about $120 \mu \mathrm{m}$ and about $4 \%$ of the particles in the sample are below $10 \mu \mathrm{m}$ in size. See Fig. 1.

\subsection{Reagents}

The reagents used in the bench flotation tests were commercial sodium silicate of modus 1, 2.26, and 3.33 as depressants (Table 2), the collector sodium oleate trade mark Dinâmica, and the $\mathrm{pH}$ modifiers $\mathrm{NaOH}$ Dinâmica and $\mathrm{HCl}$ trade mark Vetec.

For bench flotation tests, $1 \%$ sodium oleate (wt/v) and $5 \%$ sodium silicate $(\mathrm{wt} / \mathrm{v})$ were prepared. The sodium oleate solution $(1 \% \mathrm{wt} / \mathrm{v})$ was prepared by dilution of $1 \mathrm{~g}$ of oleic acid with $10 \mathrm{~mL}$ of distilled water followed by the addition of $1.7 \mathrm{~mL}$ of sodium hydroxide solution of $10 \%(\mathrm{wt} / \mathrm{v}$ ) concentration under constant stirring until a limpid and yellow colour solution was obtained. Finally, the solution obtained was diluted with distilled water to a volume of $100 \mathrm{~mL}$. The $5 \%$ (wt/v) sodium silicate solution was prepared by dilution of an appropriate weight of reagent, corresponding to $5 \mathrm{~g}$ in accordance with the data presented in Table 2, with distilled water under constant stirring until a limpid solution was obtained. Finally, the solution obtained was diluted with distilled water to a volume of $100 \mathrm{~mL}$.

\subsection{Bench flotation tests}

The software Minitab 15 was used to plan the factorial experiment design of the bench flotation tests and to analyse the variable responses, Fe recovery, $\mathrm{Fe}$ and $\mathrm{SiO}_{2}$ grades in the concentrates obtained. The
Table 2

Chemical composition and properties of sodium silicate samples.

\begin{tabular}{|c|c|c|c|c|c|c|}
\hline \multirow[t]{2}{*}{ Modulus } & \multirow[t]{2}{*}{$\mathrm{SiO}_{2}$} & \multirow[t]{2}{*}{$\mathrm{Na}_{2} \mathrm{O}$} & \multirow{2}{*}{$\frac{\text { Solids }}{\text { (wt.\%) }}$} & \multirow{2}{*}{$\frac{\mathrm{H}_{2} \mathrm{O}}{\text { (wt.\%) }}$} & \multirow{2}{*}{$\frac{\text { Density }}{(\mathrm{g} / \mathrm{L})}$} & \multirow{2}{*}{$\frac{\text { Viscosity }}{(\mathrm{cP})}$} \\
\hline & & & & & & \\
\hline 1 & 28.8 & 28.8 & 57.6 & 42.5 & - & - \\
\hline 2.26 & 33.3 & 14.7 & 48.0 & 52.0 & 1.6 & 1350 \\
\hline 3.33 & 29.9 & 8.9 & 38.7 & 61.3 & 1.4 & 540 \\
\hline
\end{tabular}

factorial experiment design of two levels of the variables, pulp density (60 and 70 wt.\%) (Houot, 1983), sodium silicate dosage (25 and $500 \mathrm{~g} /$ ton), and sodium oleate dosage (300 and $1200 \mathrm{~g} / \mathrm{ton}$ ) was performed with the sodium silicate of modulus 1 (SS1), 2.26 (SS2.26), and 3.33 (SS3.33).

The bench flotation tests were performed in a CIMAG cell at pH 7 (Luz, 1996; Lopes and Lima, 2009). The pulp at a desired density weight percentage was prepared with tap water and the speed of the cell was fixed at 1200 RPM. Then depressant sodium silicate was added and conditioned for $6 \mathrm{~min}$, followed by the addition of sodium oleate and conditioning for 6 more minutes. Afterwards chemical analyses were performed for $\mathrm{Fe}$ and $\mathrm{SiO}_{2}$ to calculate the metallurgical balance. Each test was performed twice with only one concentrate collected by test.

\section{Results}

Table 3 depicts the row data from the design of the variables studied (pulp density, sodium silicate, and sodium oleate dosages) on Fe recovery, $\mathrm{Fe}$ and $\mathrm{SiO}_{2}$ grades in concentrate for sodium silicate modulus of 1 (SS1), 2.26 (SS2.26), and 3.33 (SS3.33), respectively.

In general, Fe recoveries were highest (above 90\% mean) for all sodium silicates tested. Fe grades were highest for low levels of the factors pulp density and sodium silicate dosage, and at high level of sodium oleate dosage. The $\mathrm{SiO}_{2}$ grades behaved oppositely.

The mean Fe recoveries were between $93.8 \%$ (SS2.26) to $95.2 \%$ (SS3.33). The results with SS1, SS2.26 and SS3.33 are in accordance with those of Sollenberger and Greenwalt (1958) flotation of specular hematite ore with oleic acid and a mixture of sodium silicate of modulus 2.4 and 2.9 (Fe recovery of $89 \%$ with $56 \%$ acid-soluble iron). But a $2.3 \%$ increase in Fe grade in concentrates, and a 3.5\% decrease with larger sodium silicate modulus in $\mathrm{SiO}_{2}$ grade were observed.

Tables 4, 5, and 6 summarize the estimated effects and coefficients of Fe recovery, $\mathrm{Fe}$ and $\mathrm{SiO}_{2}$ grade of coded units for a confidence level of $95 \%$ (alpha $=0.05)$. Based on p-values presented in Tables 4 and 6,

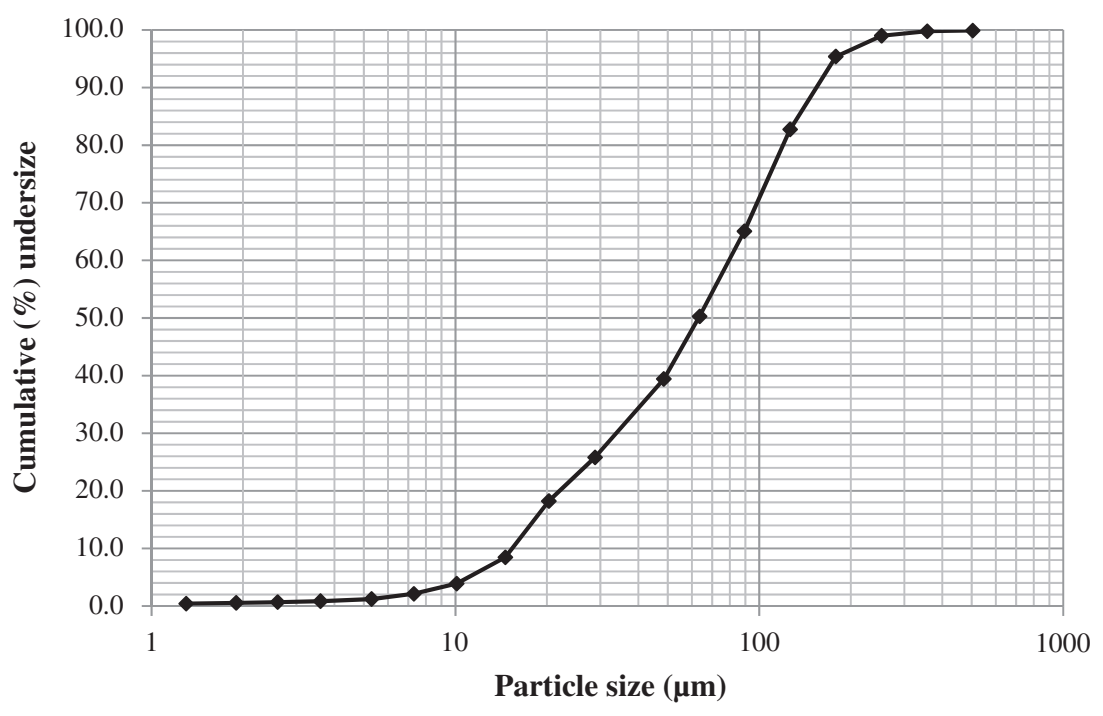

Fig. 1. Size distribution of the iron ore sample after desliming operation. 
Table 3

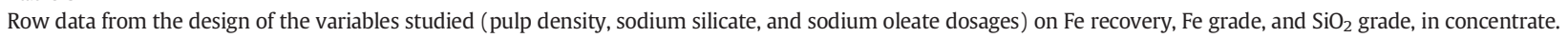

\begin{tabular}{|c|c|c|c|c|c|c|c|c|c|c|c|c|c|c|}
\hline \multicolumn{6}{|c|}{ Factors } & \multicolumn{3}{|l|}{ SS1 } & \multicolumn{3}{|l|}{ SS2.26 } & \multicolumn{3}{|l|}{ SS3.33 } \\
\hline \multicolumn{2}{|c|}{$\begin{array}{l}\text { Pulp density } \\
\text { (wt.\%) }\end{array}$} & \multicolumn{2}{|c|}{$\begin{array}{l}\text { SS } \\
\text { (g/ton) }\end{array}$} & \multicolumn{2}{|c|}{$\begin{array}{l}\text { Sodium oleate } \\
\text { (g/ton) }\end{array}$} & \multirow{2}{*}{$\begin{array}{l}\begin{array}{l}\text { Fe rec } \\
(\%)\end{array} \\
94.8\end{array}$} & \multirow{2}{*}{$\begin{array}{c}\% \mathrm{Fe} \\
47.1\end{array}$} & \multirow{2}{*}{$\begin{array}{c}\% \mathrm{SiO}_{2} \\
30.3\end{array}$} & \multirow{2}{*}{$\begin{array}{l}\text { Fe rec } \\
(\%)\end{array}$} & \multirow{2}{*}{$\begin{array}{c}\% \mathrm{Fe} \\
45.7\end{array}$} & \multirow{2}{*}{$\begin{array}{c}\% \mathrm{SiO}_{2} \\
33.0\end{array}$} & \multirow{2}{*}{$\begin{array}{l}\text { Fe rec } \\
(\%)\end{array}$} & \multirow{2}{*}{$\begin{array}{c}\text { \% Fe } \\
48.3\end{array}$} & \multirow{2}{*}{$\begin{array}{c}\% \mathrm{SiO}_{2} \\
29.7\end{array}$} \\
\hline 60 & - & 25 & - & 300 & - & & & & & & & & & \\
\hline 70 & + & 25 & - & 300 & - & 94.4 & 45.9 & 32.5 & 95.7 & 47.0 & 31.4 & 95.6 & 48.6 & 27.9 \\
\hline 60 & - & 500 & + & 300 & - & 89.1 & 48.3 & 29.6 & 90.6 & 47.5 & 30.5 & 92.9 & 49.1 & 27.7 \\
\hline 70 & + & 500 & + & 300 & - & 95.3 & 46.3 & 31.6 & 93.5 & 47.1 & 30.8 & 96.6 & 45.2 & 32.8 \\
\hline 60 & - & 25 & - & 1200 & + & 92.9 & 55.2 & 19.2 & 91.5 & 59.9 & 13.1 & 93.1 & 60.1 & 12.9 \\
\hline 70 & + & 25 & - & 1200 & + & 92.3 & 59.2 & 13.5 & 96.3 & 55.7 & 19.0 & 96.0 & 56.2 & 16.8 \\
\hline 60 & - & 500 & + & 1200 & + & 96.2 & 49.1 & 28.2 & 94.6 & 52.7 & 22.9 & 94.4 & 53.9 & 20.3 \\
\hline 70 & + & 500 & + & 1200 & + & 97.4 & 47.2 & 31.1 & 96.1 & 51.6 & 24.8 & 97.4 & 50.3 & 26.5 \\
\hline 60 & - & 25 & - & 300 & - & 94.1 & 47.1 & 30.3 & 94.7 & 47.0 & 31.1 & 93.7 & 49.9 & 27.2 \\
\hline 70 & + & 25 & - & 300 & - & 94.4 & 45.9 & 32.5 & 90.7 & 48.6 & 28.7 & 96.2 & 48.6 & 28.5 \\
\hline 60 & - & 500 & + & 300 & - & 92.0 & 44.0 & 35.3 & 94.5 & 47.9 & 30.5 & 94.7 & 47.6 & 30.2 \\
\hline 70 & + & 500 & + & 300 & - & 96.0 & 47.9 & 29.4 & 94.4 & 47.8 & 30.1 & 95.3 & 49.1 & 27.2 \\
\hline 60 & - & 25 & - & 1200 & + & 90.2 & 57.9 & 15.3 & 89.3 & 61.3 & 10.8 & 93.5 & 57.0 & 16.1 \\
\hline 70 & + & 25 & - & 1200 & + & 92,2 & 56.2 & 17.7 & 94.4 & 43.0 & 37.0 & 97.0 & 56.2 & 17.8 \\
\hline 60 & - & 500 & + & 1200 & + & 94.1 & 44.8 & 34.1 & 93.1 & 53.6 & 21.6 & 94.2 & 55.1 & 19.0 \\
\hline 70 & + & 500 & + & 1200 & + & 96.2 & 44.0 & 34.7 & 96.5 & 52.2 & 23.0 & 97.3 & 48.1 & 28.9 \\
\hline
\end{tabular}

$(-)$ low level; (+) high level.

Table 4

Summary of the estimated effects, coefficients for Fe recovery, Fe grade, and $\mathrm{SiO}_{2}$ grade of coded units for a confidence level of $95 \%$ (alpha $=0.05$ ) for $\mathrm{SS} 1$.

\begin{tabular}{|c|c|c|c|c|c|c|c|c|c|c|c|c|}
\hline \multirow[t]{2}{*}{ Term } & \multicolumn{4}{|c|}{ Fe recovery } & \multicolumn{4}{|l|}{$\% \mathrm{Fe}$} & \multicolumn{4}{|l|}{$\% \mathrm{SiO}_{2}$} \\
\hline & Effect & Coef & $\mathrm{p}$ & Significance & Effect & Coef & $\mathrm{p}$ & Significance & Effect & Coef & $\mathrm{p}$ & Significance \\
\hline \multicolumn{2}{|l|}{ Constant } & 93.9 & 0.00 & Yes & & 49.1 & 0.00 & Yes & & 27.8 & 0.00 & Yes \\
\hline A & 1.8 & 0.9 & 0.02 & Yes & -0.1 & -0.1 & 0.91 & No & 0.1 & 0.1 & 0.95 & No \\
\hline B & 1.4 & 0.7 & 0.05 & Yes & -5.3 & -2.7 & 0.00 & Yes & 7.8 & 3.9 & 0.00 & Yes \\
\hline C & 0.2 & 0.1 & 0.77 & No & 5.2 & 2.6 & 0.00 & Yes & -7.2 & -3.6 & 0.00 & Yes \\
\hline$A * B$ & 1.5 & 0.8 & 0.03 & Yes & -0.1 & -0.0 & 0.95 & No & -0.2 & -0.1 & 0.90 & No \\
\hline$A * C$ & -0.7 & -0.3 & 0.28 & No & 0.0 & 0.0 & 0.99 & No & -0.1 & -0.0 & 0.97 & No \\
\hline $\mathrm{B} * \mathrm{C}$ & 2.7 & 1.3 & 0.00 & Yes & -5.5 & -2.7 & 0.00 & Yes & 7.8 & 3.9 & 0.00 & Yes \\
\hline$A * B * C$ & -1.1 & -0.5 & 0.11 & No & -1.2 & -0.6 & 0.28 & No & 1.9 & 1.0 & 0.18 & No \\
\hline \multicolumn{5}{|c|}{ Standard deviation $=1.2$} & \multicolumn{4}{|c|}{ Standard deviation $=2.1$} & \multicolumn{4}{|c|}{ Standard deviation $=2.7$} \\
\hline
\end{tabular}

A - pulp density (wt.\%); B - SS1 (g/ton); C - sodium oleate (g/ton).

Table 5

Summary of the estimated effects, coefficients for Fe recovery, Fe grade, and $\mathrm{SiO}_{2}$ grade of coded units for a confidence level of $95 \%$ (alpha $=0.05$ ) for SS2.26.

\begin{tabular}{|c|c|c|c|c|c|c|c|c|c|c|c|c|}
\hline \multirow[t]{2}{*}{ Term } & \multicolumn{4}{|c|}{ Fe Recovery } & \multicolumn{4}{|l|}{$\% \mathrm{Fe}$} & \multicolumn{4}{|l|}{$\% \mathrm{SiO}_{2}$} \\
\hline & Effect & Coef & $\mathrm{p}$ & Significance & Effect & Coef & $\mathrm{p}$ & Significance & Effect & Coef & $\mathrm{p}$ & Significance \\
\hline Constant & & 93.8 & 0.00 & Yes & & 50.5 & 0.00 & Yes & & 27.2 & 0.00 & Yes \\
\hline A & 1.8 & 0.9 & 0.08 & No & -2.9 & -1.4 & 0.12 & No & 1.7 & 0.9 & 0.62 & No \\
\hline B & 0.8 & 0.4 & 0.43 & No & -1.0 & -0.5 & 0.56 & No & -0.9 & -0.5 & 0.80 & No \\
\hline C & 0.4 & 0.2 & 0.68 & No & 6.4 & 3.2 & 0.00 & Yes & -7.1 & -3.5 & 0.07 & No \\
\hline$A * B$ & 0.1 & 0.0 & 0.93 & No & 2.1 & 1.0 & 0.24 & No & -0.9 & -0.5 & 0.79 & No \\
\hline$A * C$ & 1.8 & 0.9 & 0.08 & No & -3.4 & -1.7 & 0.07 & No & 2.8 & 1.4 & 0.44 & No \\
\hline $\mathrm{B} * \mathrm{C}$ & 1.4 & 0.7 & 0.15 & No & -1.5 & -0.7 & 0.40 & No & -0.3 & -0.2 & 0.92 & No \\
\hline $\mathrm{A} * \mathrm{~B} * \mathrm{C}$ & -1.3 & -0.7 & 0.18 & No & & 1.5 & 0.11 & No & -1.9 & -1.0 & 0.58 & No \\
\hline \multicolumn{5}{|c|}{ Standard deviation $=1.8$} & \multicolumn{4}{|c|}{ Standard deviation $=3.3$} & \multicolumn{4}{|c|}{ Standard deviation $=6.8$} \\
\hline
\end{tabular}

A - pulp density (wt.\%); B - SS2.26 (g/ton); C - sodium oleate (g/ton).

Table 6

Summary of the estimated effects, coefficients for Fe recovery, Fe grade, and $\mathrm{SiO}_{2}$ grade of coded units for a confidence level of $95 \%$ (alpha $=0.05$ ) for $\mathrm{SS3.33.}$

\begin{tabular}{|c|c|c|c|c|c|c|c|c|c|c|c|c|}
\hline \multirow[t]{2}{*}{ Term } & \multicolumn{4}{|c|}{ Fe Recovery } & \multicolumn{4}{|l|}{$\% \mathrm{Fe}$} & \multicolumn{4}{|l|}{$\% \mathrm{SiO}_{2}$} \\
\hline & Effect & Coef & $\mathrm{p}$ & Significance & Effect & Coef & $\mathrm{p}$ & Significance & Effect & Coef & $\mathrm{p}$ & Significance \\
\hline \multicolumn{2}{|l|}{ Constant } & 95.2 & 0.00 & Yes & & 51.5 & 0.00 & Yes & & 24.3 & 0.00 & Yes \\
\hline A & 2.4 & 1.2 & 0.00 & Yes & -2.3 & -1.2 & 0.02 & Yes & 2.9 & 1.5 & 0.02 & Yes \\
\hline B & 0.3 & 0.1 & 0.48 & No & -3.3 & -1.7 & 0.00 & Yes & 4.5 & 2.2 & 0.00 & Yes \\
\hline C & 0.3 & 0.1 & 0.49 & No & 6.3 & 3.2 & 0.00 & Yes & -9.1 & -4.6 & 0.00 & Yes \\
\hline$A * B$ & 0.2 & 0.1 & 0.67 & No & -0.9 & -0.5 & 0.26 & No & 1.6 & 0.8 & 0.14 & No \\
\hline$A * C$ & 0.7 & 0.4 & 0.11 & No & -1.5 & -0.7 & 0.09 & No & 2.5 & 1.3 & 0.04 & Yes \\
\hline $\mathrm{B} * \mathrm{C}$ & 0.7 & 0.3 & 0.14 & No & -2.2 & -1.1 & 0.02 & Yes & 3.3 & 1.7 & 0.01 & Yes \\
\hline $\mathrm{A} * \mathrm{~B} * \mathrm{C}$ & -0.3 & -0.1 & 0.52 & No & -0.6 & -0.3 & 0.46 & No & 1.0 & 0.5 & 0.35 & No \\
\hline \multicolumn{5}{|c|}{ Standard deviation $=0.8$} & \multicolumn{4}{|c|}{ Standard deviation $=1.5$} & \multicolumn{4}{|c|}{ Standard deviation $=2.0$} \\
\hline
\end{tabular}

A - pulp density (wt.\%); B - SS3.33 (g/ton); C - sodium oleate (g/ton). 

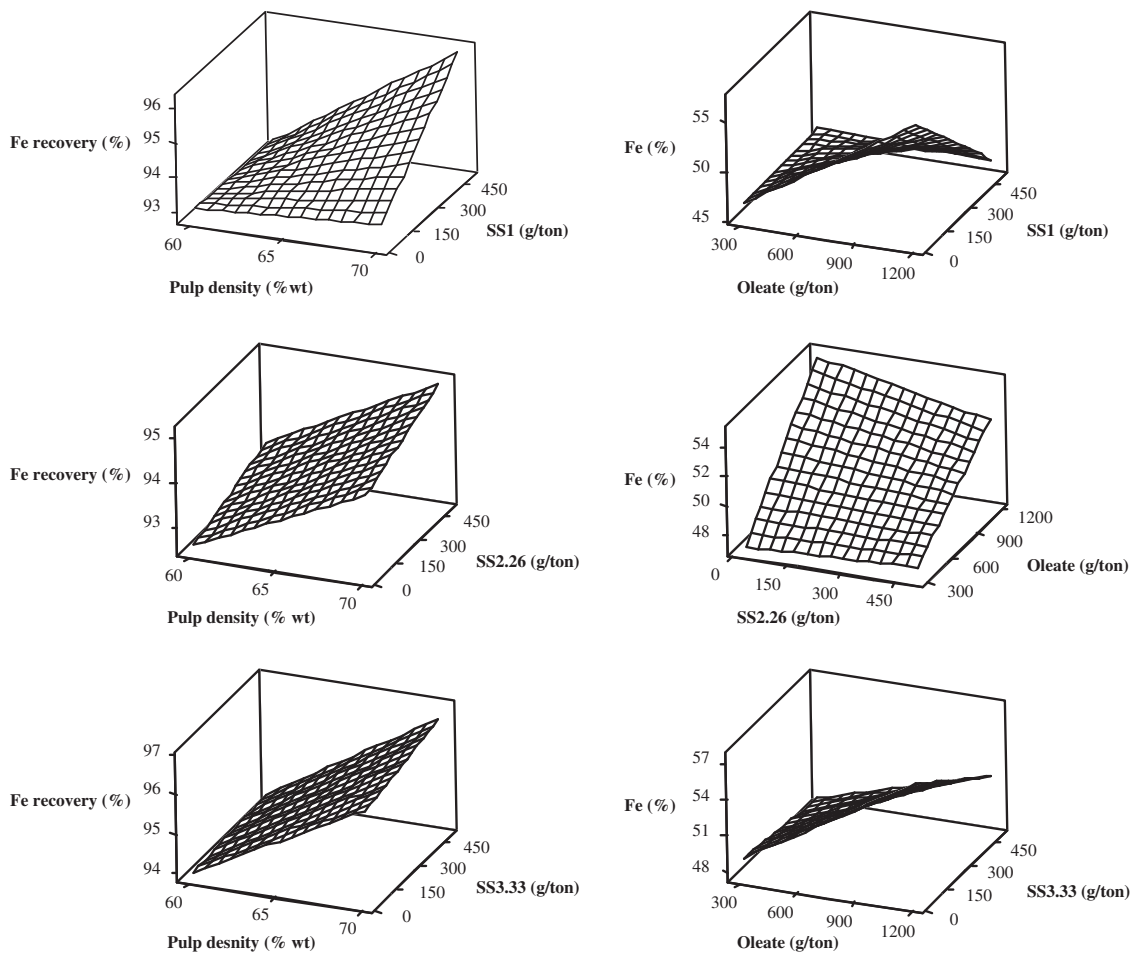
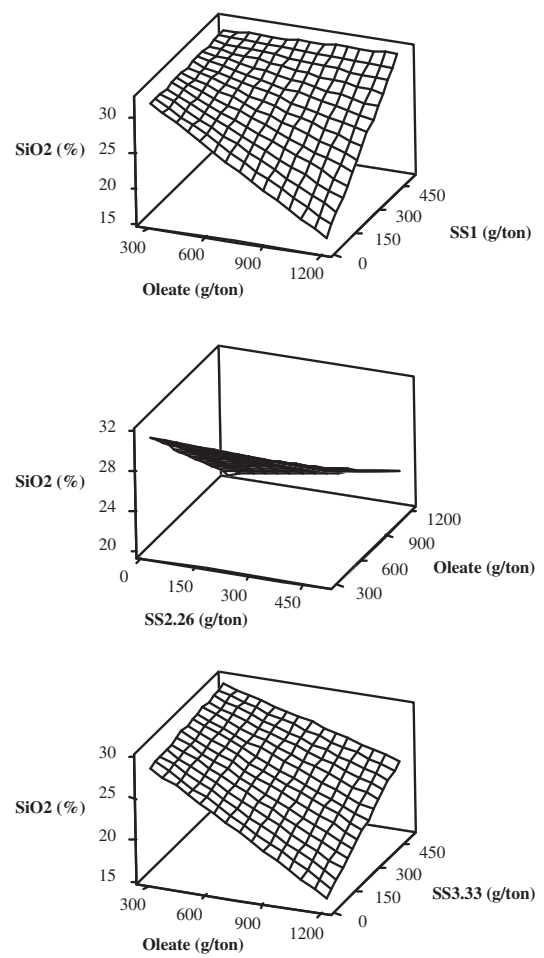

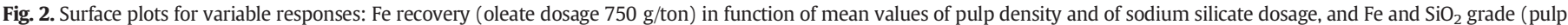
density $65 \%$ ) in function of mean values of sodium silicate and sodium oleate dosage.

Fig. 2 presents surface plots for the main significant factors for Fe recovery and $\mathrm{Fe}$ and $\mathrm{SiO}_{2}$ grades for all sodium silicate modulus.

\section{Conclusions}

Based on the results of bench flotation tests of an actual sample of iron ore that was observed, iron recoveries were above $90 \%$ and Fe contents were above $55 \%$ in the concentrate for all sodium silicate tested. In general, the highest $\mathrm{Fe}$ grade and the lowest $\mathrm{SiO}_{2}$ grade came from low pulp density (60\%) and sodium silicate dosage ( $25 \mathrm{~g} / \mathrm{ton})$ and at high level of sodium oleate ( $1200 \mathrm{~g} / \mathrm{ton})$. The increase of sodium silicate modulus had a small influence on response variables: Fe recovery increased $\sim 1.4 \%$, Fe grade increased $\sim 2.3 \%$, and $\mathrm{SiO}_{2}$ grade decreased $\sim 3.5 \%$ in SS3.33 compared with SS1.

\section{Acknowledgements}

The financial support by the CNPq, the FAPEMIG, the Vale, and the CAPES is gratefully acknowledged.

\section{References}

Al-Wakeel, M.I., El-Rahman, 2006. Beneficiation of low grade Ghorabi iron ore, Bahariya Oasis, Egypt: a case study. Miner. Process. Extr. Metall. (Trans. Inst. Mineral Metall. C) 115 (no 4), 177-182.

Araújo, A.C., Amarante, S.C., Souza, C.C., Silva, R.R.R., 2003. Ore mineralogy and its relevance for selection of concentration methods in processing of Brazilian iron ores. Miner. Process. Extr. Metall. (Trans. Inst. Min. Metall. C). 112, C44-C64.

Bass, J.L., Turner, G.L., 1997. Anion distributions in sodium silicate solutions. Characterization by 29Si NMR and infrared spectroscopies, and vapor phases osmometry. J. Phys. Chem. B 101, 10638-10644
Gutierréz, C., Iskra, J., 1977. The action of neutral oleic acid in the flotation of hematite. Int. J. Miner. Process. 4, 163-171.

Houot, R., 1983. Beneficiation of iron ore by flotation - review of industrial and potentia applications. Int. J. Miner. Process. 10 (3), 183-204.

Ingri, N., 1959. Equilibrium studies of polyanions IV. Silicate ions $\mathrm{NaCl}$ medium. Acta Chem. Scand. 13, 758-775.

Jung, R.F., James, R.O., Healy, T.W., 1987. Adsorption, precipitation, and electrokinetic processes in iron ore oxide (goethite) - oleic acid - oleate system. J. Colloid Surf. Sci. 118 (2), 463-472.

Kulkarni, R.D., Somasundaran, P., 1975. Kinetics of oleate adsorption at the liquid/air interface and its role in hematite flotation. AIChE Symp. 71, 124-133.

Lagerström, C., 1959. Equilibrium studies of polyanions III. Silicate ions in $\mathrm{NaClO} 4$ medium. Acta Chem. Scand. 13, 722-736.

Leja, J., 1982. Surface Chemistry of Froth Flotation. Plenum Press, New York (758 pp.).

Lopes, G.M., Lima, R.M.F., 2009. Flotação direta de minério de ferro com oleato de sódio. REM: R. Esc. Minas 62 (3), 323-329.

Luz, J.A.M., 1996. Flotação aniônica de rejeito itabirítico: estudo de reagentes alternativos e modelamento polifásico do processo. Thesis (Doutorado em Engenharia Metalúrgica e de Minas) Universidade Federal de Minas Gerais, Belo Horizonte (574 pp.).

Ma, M., 2011. The dispersive effect of sodium silicate on kaolinite particles in process water: implication for iron-ore processing. Clays Clay Miner. 59 (3), 233-239.

Shibata, J., Fuerstenau, D.W., 2003. Flocculation and flotation characteristic of fine hematite with sodium oleate. Int. J. Miner. Process. 72, 25-32.

Sjöberg, S., Öhman, L., Ingri, N., 1985. Equilibrium and structural studies of silicon (IV) and aluminium (III) in aqueous solution. 11. Polysilicate formation in alkaline aqueous solution. A combined potentiometric and ${ }^{29}$ Si NMR study. 1985. Acta Chem. Scand. A 39 93-107.

Sollenberger, C.L., Greenwalt, R.B., 1958. Relative effectiveness of sodium silicate of different silica-soda ratios as gangue depressants in nonmetallic flotation. Transactions AIME. Min. Eng. 691-693.

Svensson, I.L., Sjöberg, S., Öhman, L, 1986. Polysilicate equilibria in concentrated sodium silicate solutions. J. Chem Soc. Faraday Trans. 86, 3635-3646.

Uwadiale, G.G.O.O., 1992. Flotation of iron oxides and quartz: a review. Miner. Process. Extr. Metall. Rev. 11, 129-161.

Zhang, P., Snow, R., Peres, A.E.C., El-Shall, H., El-Midany, A., 2007. Depressants in nonsulfide minerals flotation. In: Fuerstenau, M.C., Jameson, G., Yonn, R. (Eds.), Froth Flotation: A Century of Innovation, pp. 555-574. 